\title{
Technological basis of processing of serpentinite copper-gold ores in the Kyrgyz Republic
}

\author{
Kulzhamal Nogaeva ${ }^{1}$, Yessil Alpiyev ${ }^{2}$, Almaz Kozhonov$^{1}$, Valerii Korniyenko ${ }^{3}$, and Yevhenii Malanchuk ${ }^{3}$ \\ ${ }^{1}$ Kyrgyz state university of geology, mining, and natural resources development named after academician U. Asanaliev, 215 Chui Ave, \\ Bishkek, Kyrgyz Republic \\ ${ }^{2}$ KAZ Minerals Bozymchak LLC, 109 Kalyk Akiev Str., Bishkek, Kyrgyz Republic \\ ${ }^{3}$ National University of Water and Environmental Engineering, 11 Soborna Str., Rivne, 33028, Ukraine
}

\begin{abstract}
Annotation. The article is devoted to the development of an effective technology for processing serpentinite ores from the Bozymchak deposit in the Kyrgyz Republic. Based upon the analysis of mineralogical, physical and chemical parameters of the ore, the authors set reasons for the decrease in technological indicators of the existing concentrator and determine concentrating properties of the reviewed serpentinite resistant material by applying methods of intensifying the flotation process by using additional flotation collectors/depressors and introducing the process of mechanochemical activation of the pulp before flotation. In the proposed technological flowsheet, main requirements for the technological flowsheet and reagent suite of processing serpentinite ores are formed and it is acknowledged that an increase in the grinding size, introduction of the selective copper collector and additional depressor determines the prospects for improving the "reagent" component of determining factors of the set task. Materials of the article can be useful for mining and processing enterprises while involving resistant copper bearing, magnesian serpentinite ores in the processing in order to increase the raw material base of the existing mining and processing complex.
\end{abstract}

\section{Introduction}

The subject of research is serpentinite ores of the Bozymchak deposit in the Kyrgyz Republic. Serpentinite ores are composed of serpentine minerals (antigorite, chrysotile), carbonates, pyroxene, amphibole, and quartz. The main target copper mineral in this type of ore is chalcopyrite. The grade of secondary and oxidized copper minerals in some samples can reach $50 \%$ of the total amount of copper bearing minerals. The grade of serpentine reaches $70-71 \%$. Main components in the ore are copper, gold, silver [1, 2].

According to the geological exploration, main reserves (up to $70 \%$ ) of the Bozymchak gold and copper deposit are accounted for by serpentinite ores, which, in turn, determines the priority of developing processing technology for this type of raw material.

The ore mineral composition of the deposit is predetermined by the complex tectonic environment of their formation: introduction of granitoid intrusion contact metamorphism with formation of marbles, corneas, serpentinites and skarns - pre-ore discontinuous tectonics - superposition of hydrothermal processes.

In this regard, two types of ores are developed at the deposit: skarn and serpentinite. Rock-forming minerals of ore skarns are represented by wollastonite, garnet (andradite), pyroxene (augite), quartz, slightly epidote, chlorite, and carbonates. Sulphide minerals are represented by chalcopyrite, bornite, chalcosine, covelline, pyrite.

Serpentinite is a rock consisting mainly of minerals of the serpentine group: lizardite, antigorite, chrysotile, chrysotile-asbestos that have a common chemical formula: $\mathrm{X}_{2}-3 \mathrm{Si}_{2} \mathrm{O} 5(\mathrm{OH})_{4}$, where $\mathrm{X}=\mathrm{Mg}, \mathrm{Fe}^{2+}, \mathrm{Fe}^{3+}, \mathrm{Ni}$, $A l, Z n, M n$. Serpentinite is the host rock of many minerals or frames deposits and therefore is a multi-tonnage waste of the mining industry and processing industry [3]. Serpentinite consists mainly of magnesium hydrosilicates, the processing of which makes it possible to obtain magnesium oxide and silicon dioxide.

When processing serpentinite, along with magnesium, concentrates of non-ferrous metals are obtained. Serpentine is leached with hydrochloric acid to obtain chlorinated magnesium solution and silicon dioxide. Chlorine-magnesium solution is purified from impurities by neutralization to obtain an iron-nickel concentrate. Carnallite is synthesized from purified chlorinemagnesium solution [4].

Serpentine-bearing ores can be an unconventional source of magnesium salts, white soot, iron-bearing pigments, and chromite concentrate and chromium compounds. It is proposed to use sulfuric or nitric acid methods for processing of serpentinites. Unlike sulfuric acid, serpentized magnesium and iron-magnesium silicates containing serpentine anthophyllite, talc, quartz, aluminum silicate, clinochlor, and the mineral nontronite, 
pimelite are leached with the participation of Bacillus bacteria, and nickel sulphides are not leached $[5,6]$.

The low quality of the copper concentrate is due to the presence of serpentine in it, the mass fraction of which reaches $43 \%$, and presence of intergrowth of iron oxides with chalcopyrite. Losses of copper with dump tailings are associated with its losses with chrysocolla (losses of this mineral with dump tailings are 100\%), malachite and azurite (losses of free copper oxides with dump tailings are $90 \%$ ), and with intergrowth of chalcopyrite with iron oxides [7-9].

For enrichment of serpentinite asbestos ores, friction enrichment, air separation and wet processes are used [10]. To preserve the natural length of high-grade asbestos fibers and maximize their extraction, staged crushing is widely used with the extraction of asbestos fibers as they are released from their connection with the host rocks.

Main difficulties in concentrating of serpentinite ores are associated with the complexity of the ore mineral composition of the waste, among which easy-to-float serpentine minerals predominate.

\section{Methods of experiment procedure}

The study of the mineral composition of ore and concentrating products was performed using an Axio Imager A1m optical microscope equipped with automated Mineral C7 analyzer and EVO-MA 15 electronic scanning microscope. X-ray phase analysis of ore was performed on ARL PERFORM'X wave $\mathrm{X}$-ray fluorescence spectrometer.

$\mathrm{XRD}$ analysis of the initial ore was performed on $\mathrm{x}-$ ray diffractometer of powder materials XRD-7000S. Weight parts of valuable components in the initial ore and its processed products were measured using Arcos, inductively coupled plasma emission spectrometer, Solaar, atomic absorption spectrometer, CS-800 sulfur analyzer, Titration Excellence T-70 automatic titration system, and Specord 250 Plus scanning spectrophotometer.

Sample preparation and technological studies were performed using MShL-7 ball mill, ultrafine bead mill, Pulverisette-5 planetary mill, flotation machines FMP-L3, FMP-L1 and FMP-L0.3.

According to the program of works, liberation of ore minerals in serpentinite samples was studied when the samples were grinded to $86.8 \%-71 \mu \mathrm{m}$.

In order to determine preliminarily technological indicators of the processability of serpentinite ore samples, flotation tests were performed according to the existing engineering report and with the use of new collectors. A number of traditional (liquid glass, carboxymethylcellulose) and new generation reagents (modified polysaccharides) were considered as depressors. Considering the work on copper bearing ores with the flotation-active rock-containing component, a series of experiments with the collector/depressor combination using Aero 9863 collector were carried out.

Options with regrinding of the foam product by combined (mechanochemical) activation of the feed before cleaner flotations are considered - as a softened option of grinding to ensure access of reagents to the "fresh" surface. Sulfuric acid was used as a chemical agent. Fig. 1 shows flowsheet of experiments.

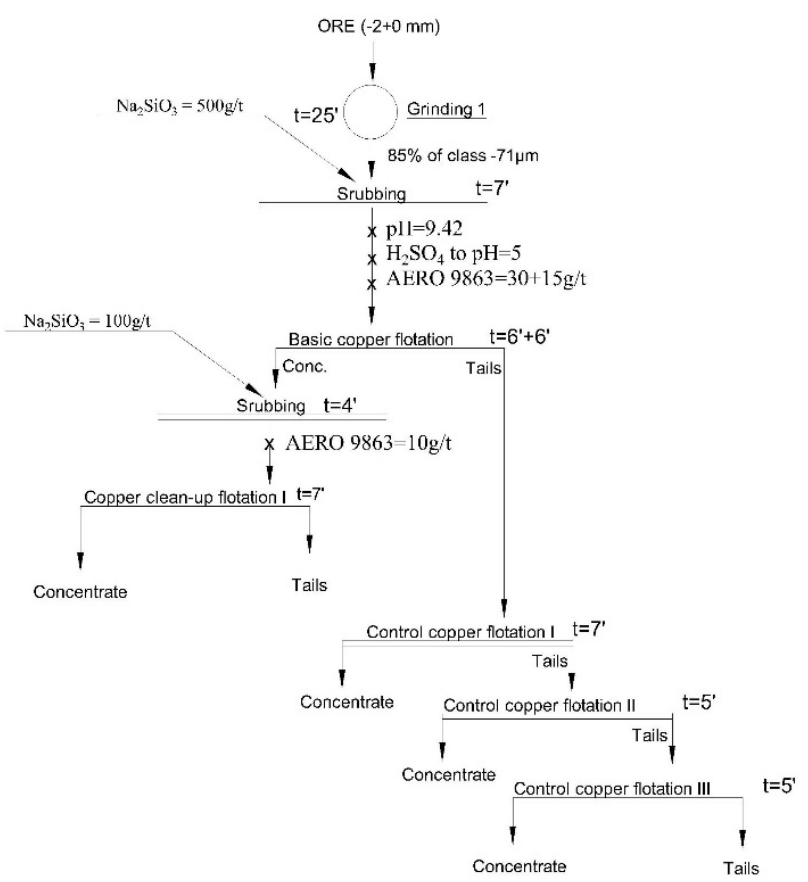

Fig. 1. Flotation flowsheet with mechanochemical activation of flotation feed.

Based upon the results of flowsheet studies, serpentinite ore flotation was carried out in closed cycle (Fig. 2).

Total reagent costs in closed cycle:

* Lime to the recommended $\mathrm{pH}$ values;

* $\mathrm{Na}_{2} \mathrm{SiO}_{3}-1000 \mathrm{~g} / \mathrm{t}$;

* Aeroflot butyl - $40 \mathrm{~g} / \mathrm{t}$;

* ACC $-100 \mathrm{~g} / \mathrm{t}$;

* Aero $9863-10 \mathrm{~g} / \mathrm{t}$;

* $\mathrm{CMC}-150 \mathrm{~g} / \mathrm{t}$

* $\mathrm{MIBC}-44 \mathrm{~g} / \mathrm{t}$

The material composition of on-balance products of serpentinite ore flotation in closed cycle is determined.

\section{Experiment results}

The results of complex mineralogical analysis, including $\mathrm{XRD}$, optical micro and macroscopic analyses are presented in Table 1.

According to mineralogical analysis, samples consist of magnesium silicates, among which serpentine predominates. Fe oxides and carbonates are present in significant amounts in the sample. The content of sulphide minerals is $10.6 \%$ by weight, of which pyrite predominates $(8.1 \%$ by weight); chalcopyrite accounts for $2.2 \%$ by weight. The sample also contains $0.28 \%$ of oxidized copper minerals, represented by malachite and chrysocolla in approximately equal amounts.

According to chemical analysis, the main rockforming elements are $\mathrm{MgO}$ and $\mathrm{SiO} 2$. Table 2 provides the chemical and phase composition of samples. 


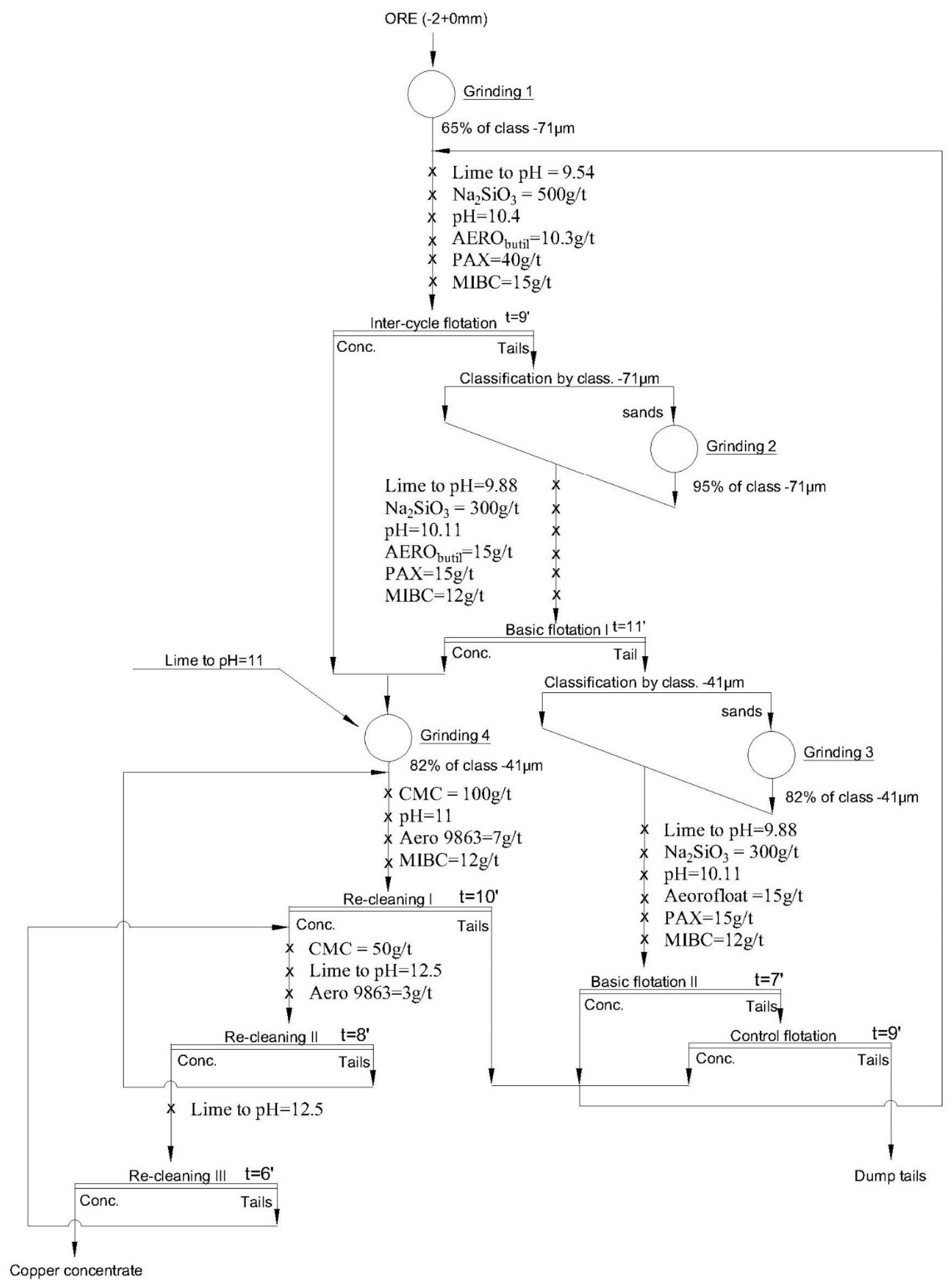

CMC - Carboxymethyl cellulose

$\mathrm{AERO}_{\text {butil }}$ - Butyl aeroflot

MIBC - Methylisobutylcarbinol

AERO 9863 - collector AERO 9863 Promoter

Fig. 2. Flowsheet of carrying out closed cycle with regrinding of the rougher concentrate. 
Table 1. Mineralogical composition of samples.

\begin{tabular}{|c|c|c|}
\hline Minerals/groups of minerals & \begin{tabular}{|c|} 
Sample \\
1
\end{tabular} & \begin{tabular}{|c|} 
Sample \\
2 \\
\end{tabular} \\
\hline Rock-forming: & $\begin{array}{l}\text { weight } \\
\%\end{array}$ & $\begin{array}{l}\text { weight } \\
\%\end{array}$ \\
\hline Serpentine $\mathrm{Mg}_{6}\left[\mathrm{Si}_{4} \mathrm{O}_{10}\right](\mathrm{OH})_{8}$ & 50.0 & 72.5 \\
\hline Pyroxenes $\mathrm{Ca}(\mathrm{Mg}, \mathrm{Fe}, \mathrm{Al})\left[(\mathrm{Si}, \mathrm{Al})_{2} \mathrm{O}_{6}\right]$ & 14.0 & 5.0 \\
\hline Amphiboles $\mathrm{Ca}_{2}(\mathrm{Mg}, \mathrm{Fe})_{5}\left[\mathrm{Si}_{4} \mathrm{O}_{11}\right]_{2}(\mathrm{OH})_{2}$ & 7.0 & 6.5 \\
\hline Magnesium silicates (chlorites) & 5.0 & 8.0 \\
\hline $\begin{array}{l}\text { Mica (biotite, phlogopite) } \\
\mathrm{K}(\mathrm{Mg}, \mathrm{Fe})_{3}\left[\mathrm{AlSi}_{3} \mathrm{O}_{\mathrm{IO}}\right](\mathrm{OH}, \mathrm{F})_{2} \\
\end{array}$ & 5.0 & i. .5 \\
\hline $\begin{array}{l}\text { Oxides } \mathrm{Fe} \text { (magnetite, hematite, } \\
\text { goethite) }\end{array}$ & 4.5 & 3.0 \\
\hline Calcite & 2.3 & 1.1 \\
\hline Total & 88.8 & 97.6 \\
\hline \multicolumn{3}{|l|}{ Sulphides: } \\
\hline Pyrite (marcasite) & 8.1 & 1.0 \\
\hline Chalcopyrite & 2.2 & 0.61 \\
\hline Wallerit $\mathrm{CuFeS}_{2}\left(\mathrm{Mg}, \mathrm{Fe}, \mathrm{Al}(\mathrm{OH})_{2-3}\right)$ & 0.1 & 0.2 \\
\hline \begin{tabular}{|lll} 
& Total \\
\end{tabular} & 10.6 & 1.9 \\
\hline $\begin{array}{l}\text { Oxidized copper minerals (malachite, } \\
\text { chrysocolla) }\end{array}$ & - & 0.28 \\
\hline Other (rutile, sphene, apatite) & 0.6 & 0.2 \\
\hline TOTAL & 100.0 & 100.0 \\
\hline
\end{tabular}

Table 2. Chemical composition of samples.

\begin{tabular}{|c|c|c|c|c|}
\hline Item & \multicolumn{2}{|c|}{ Sample 1} & \multicolumn{2}{|c|}{ Sample 2} \\
\hline Element & abs. \% & rel. & abs. $\%$ & rel. \% \\
\hline$C u$ oxidized & 0.064 & 6.7 & 0.16 & 31.4 \\
\hline Cи secondary сульфидов & 0.086 & 9.1 & 0.07 & 13.7 \\
\hline Cu primary сульфидов & 0.8 & 84.2 & 0.28 & 54.9 \\
\hline$C u_{\text {total }}$ & 0.95 & 100.0 & 0.51 & 100.0 \\
\hline$F e_{\text {total }}$ & 8.8 & & 3.88 & \\
\hline$S_{\text {sulphide }}$ & 5.12 & & 0.80 & \\
\hline$S_{\text {total }}$ & 5.19 & & 0.88 & \\
\hline $\mathrm{CO} 2$ (carbon) & 0.99 & & 0.51 & \\
\hline$C_{\text {total }}$ & 0.33 & & 0.19 & \\
\hline$P b$ & 0.006 & & $<0.005$ & \\
\hline$Z n$ & 0.056 & & 0.028 & \\
\hline Mo & 0.0026 & & 0.0014 & \\
\hline $\mathrm{MgO}$ & 27.3 & & 37.5 & \\
\hline $\mathrm{SiO}_{2}$ & 33.1 & & 34.8 & \\
\hline $\mathrm{CaO}$ & 6.68 & & 2.91 & \\
\hline AI2O3 & 1.81 & & 0.88 & \\
\hline $\mathrm{K} 2 \mathrm{O}$ & 0.31 & & 0.084 & \\
\hline $\mathrm{Na}_{2} \mathrm{O}$ & 0.023 & & 0.035 & \\
\hline $\mathrm{TiO}_{2}$ & 0.13 & & 0.1 & \\
\hline $\mathrm{MnO}$ & 0.09 & & 0.1 & \\
\hline$P 2 O 5$ & 0.014 & & 0.008 & \\
\hline$A u, \mathrm{~g} / \mathrm{t}$ & 1.12 & & 0.44 & \\
\hline$A g, \mathrm{~g} / \mathrm{t}$ & 4.91 & & 3.15 & \\
\hline
\end{tabular}

There is a noticeable difference in the phase composition of copper (Fig. 2).

According to XRD analysis (Fig. 3), main mineral phases in samples are minerals of the serpentine group $\mathrm{Mg}_{6}\left[\mathrm{Si}_{4} \mathrm{O}_{10}\right](\mathrm{OH})_{8}$. Samples also contain significant amounts of pyroxenes (diopside, augite), calcite.

Figure 3 shows intergrowth of sulphide minerals in the initial serpentinite ore.

Microscopically the bulk of serpentinites has the fibrous, thin-scaled structure characteristic of serpentine minerals, sometimes cellular with $\mathrm{Fe}$ oxides and rare inclusions of sulphide minerals. Serpentine develops along sinuous fractures with formation of the very characteristic cellular structure. The process of serpentinization of olivine is often so intense that it is almost completely replaced by the secondary mineral. Only small relic grains of unchanged olivine are usually preserved in the mass of serpentine. Rare sulphide minerals in serpentinite samples are represented by cobaltine, arsenopyrite, and cobaltpentlandite, which are closely associated with main sulphides, and are found in the chalcopyrite-pyrite fine-grained mass.

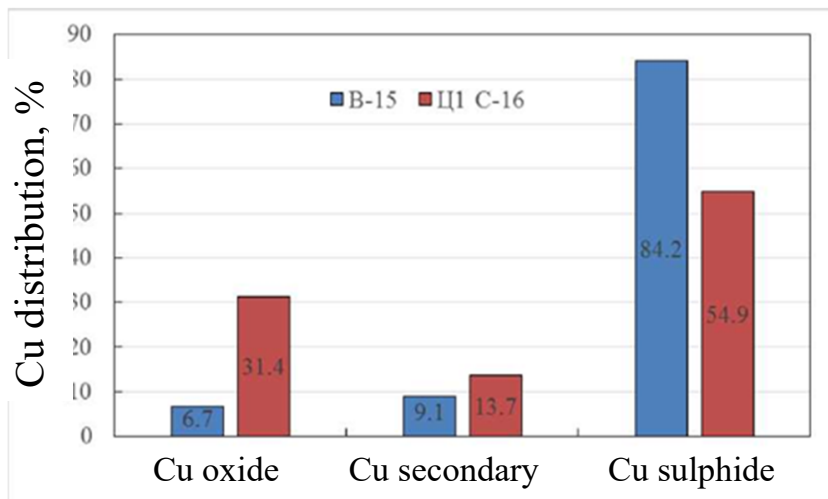

Fig. 2. The phase composition of copper in the original samples of the serpentine type.

According to the studies results on liberation, the liberation of the main sulphide mineral of copperchalcopyrite in the initial sample is $64.3 \%$ rel., when it is grinded to $86.8 \%$ - $71 \mu \mathrm{m}$. Moreover, the size of free grains of chalcopyrite on $55.1 \% \mathrm{rel}$. is concentrated in the size from 10 to $71 \mu \mathrm{m}$. The significant share is free grains of chalcopyrite in size less than $10 \mu \mathrm{m}(31.0 \%$ rel.). Main intergrowth of chalcopyrite is with non-metallic minerals $(24.6 \%$ rel.), where the main copper sulphide is represented by $73.3 \%$ rel. in size from 10 to $40 \mu \mathrm{m}$. The significant part of chalcopyrite is concentrated in polymineral intergrowths $(6.1 \% \mathrm{rel}$.$) , where it is mainly$ in the form of very thin inclusions. Pyrite liberation is $64.2 \%$ rel. Free pyrite grains are mainly concentrated in the size from 10 to $71 \mu \mathrm{m}$. It is noted that the significant part of free pyrite falls on the size less than $10 \mu \mathrm{m}(32.3 \%$ rel.). Pyrite is characterized by intergrowths with iron oxides $(17.7 \%$ rel.), where they represent the subgraphic structure of intergrowth in each other. Pyrite is $12.5 \%$ rel. represented in polymineral intergrowths and $4.9 \%$ rel. in intergrowths with non-metallic minerals.

Under flotation according to the existing engineering report, first of all, the change in the visual characteristics of flotation should be noted: process of rougher and scavenger flotation is accompanied by excessive frothing and its resistance, froth color is mainly gray, there is no contribution of copper minerals to the color gamma. The mass pull of the rougher copper concentrate is $20.3 \%$ (vs. $3.6 \%$ for sulphide ore) with metal grade of $3.69 \%$ (vs. 25.5 for sulphide ore). The selectivity of the process is broken due to the flotation-active rock-forming component. In addition, copper losses with dump tailings were $23.19 \%$. 


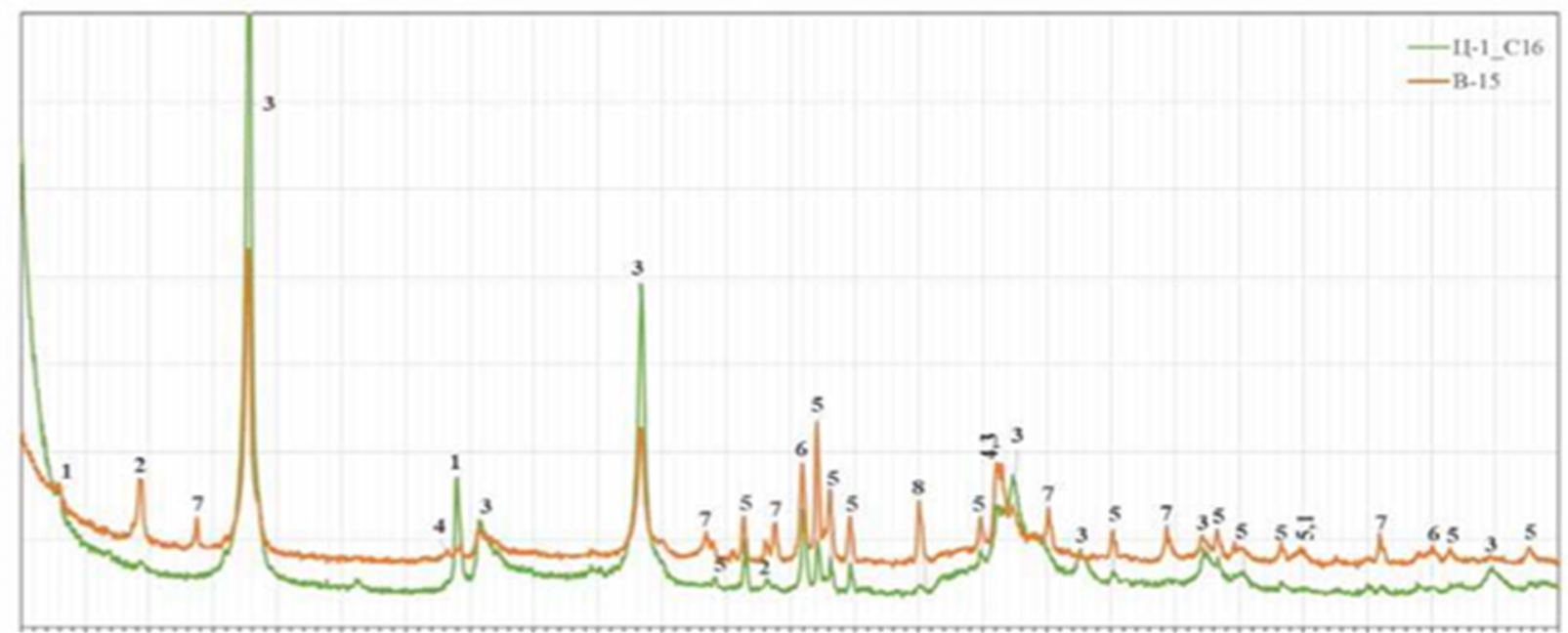

Fig. 4. Diffractograms of serpentinite samples with the designation of main mineral phases: 1 - chlorite, 2 - mica, 3 - serpentine, 4 magnetite, 5 - pyroxenes (diopside, augite), 6 - calcite, 7 - amphiboles (actinolite), 8 - pyrite.
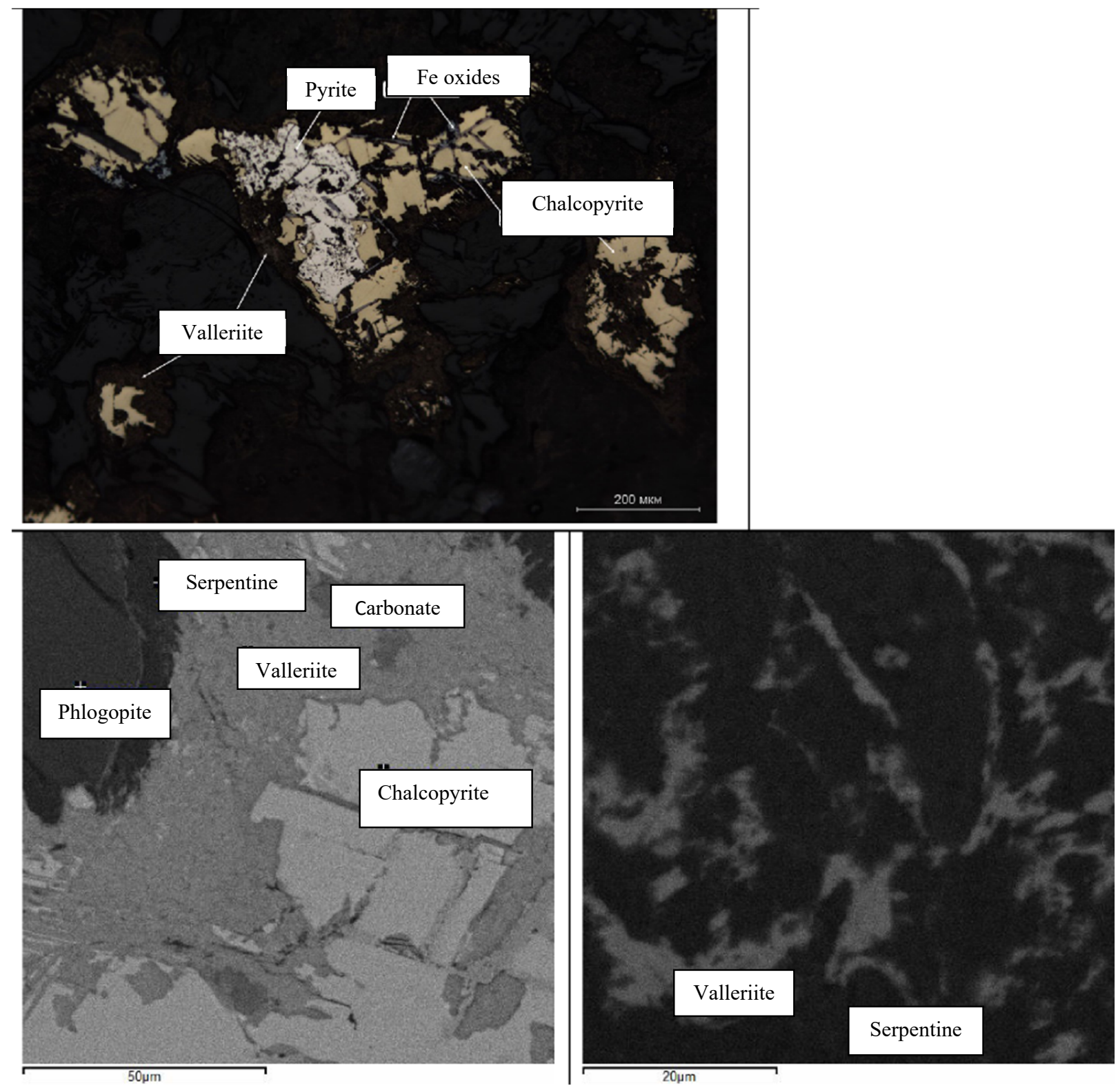

Fig. 4. Characteristic intergrowths of sulphide minerals in the original serpentinite ore. 
Mineralogical analysis of flotation products showed that main metal losses are associated with the underliberation of chalcopyrite and its thin intergrowth.

Table 3 shows the results.

Table 3. The results of flotation on the existing engineering report.

\begin{tabular}{|c|c|c|c|c|c|c|c|c|c|c|}
\hline \multirow{2}{*}{$\begin{array}{l}\text { Experience } \\
\text { conditions }\end{array}$} & \multirow{2}{*}{ Product name } & \multirow{2}{*}{$\begin{array}{c}\text { Yield } \\
\% \\
\end{array}$} & \multicolumn{4}{|c|}{ Content, \% } & \multicolumn{4}{|c|}{ Recovery, \% } \\
\hline & & & Си & $\mathrm{Fe}$ & SiO2 & $\mathrm{CaO}$ & Си & $\mathrm{Fe}$ & $\mathrm{Si}_{2}$ & $\mathrm{CaO}$ \\
\hline \multirow{5}{*}{$\begin{array}{c}85 \% \text { of class - } \\
71 \mu \mathrm{m} ; P A X- \\
70 \mathrm{~g} / t ; \mathrm{MIBC}- \\
10 \mathrm{~g} / \mathrm{t} ; P A X- \\
25+20 \mathrm{~g} / \mathrm{t} ; \mathrm{t}= \\
\quad 6 \mathrm{~min}\end{array}$} & $\begin{array}{l}\text { Basic copper } \\
\text { flotation } \\
\text { concentrate }\end{array}$ & 20,3 & 3,19 & 15 & 23,94 & 4,2 & 70,4 & 37,6 & 14,13 & 13,16 \\
\hline & \begin{tabular}{|l|} 
Concentrate \\
control \\
copper \\
flotation I \\
\end{tabular} & 2,2 & 1,82 & 19 & 22,66 & 4,4 & 4,36 & 4,93 & 1,45 & 1,49 \\
\hline & $\begin{array}{l}\text { Concentrate } \\
\text { control } \\
\text { copper } \\
\text { flotation II } \\
\end{array}$ & 1,34 & 1,37 & 16 & 21,8 & 3,6 & 2 & 2,64 & 0,85 & 0,75 \\
\hline & Tails & 76,15 & 0,28 & 5,9 & 37,75 & 7,2 & 23,2 & 54,8 & 83,57 & 84,6 \\
\hline & Руда & 100 & 0,92 & 8,3 & 34,4 & 6,48 & 100 & 100 & 100 & 100 \\
\hline
\end{tabular}

A certain effect is achieved when using organic reagents DLM62 and CMC 55C as a depressor, and liquid glass with the constant consumption $(200 \mathrm{~g} / \mathrm{t})$.

Table 4. The results of flotation using depressors.

\begin{tabular}{|l|c|c|c|c|c|}
\hline \multirow{2}{*}{ Experiment condition } & \multicolumn{4}{|c|}{ Recovery to total concentrate, \% } \\
\cline { 2 - 6 } & $\mathrm{Cu}$ & $\mathrm{Fe}$ & $\mathrm{AlO}_{3}$ & $\mathrm{SiO}_{2}$ & $\mathrm{MgO}$ \\
\hline without depressor & 76.81 & 45.2 & 17.32 & 16.43 & 19.29 \\
\hline liquid glass $-200 \mathrm{~g} / \mathrm{t}$ & 82.64 & 51.61 & 13.65 & 15.54 & 17.01 \\
\hline $\mathrm{CMC} 55 \mathrm{C}-200 \mathrm{~g} / \mathrm{t}$ & 83.48 & 52.58 & 17.27 & 15.19 & 18.03 \\
\hline AERO $8860-200 \mathrm{~g} / \mathrm{t}$ & 83.22 & 52.74 & 19.82 & 19.19 & 21.8 \\
\hline DLM $62-200 \mathrm{~g} / \mathrm{t}$ & 82.66 & 50.61 & 15.08 & 14.93 & 16.92 \\
\hline DLM $263-200 \mathrm{~g} / \mathrm{t}$ & 82.93 & 53.1 & 21.52 & 17.97 & 18.29 \\
\hline
\end{tabular}

The main increase in metal recovery (about $6 \%$ ) is due to redistribution of the share of $\mathrm{FeO}$ and $\mathrm{Al}_{2} \mathrm{O}_{3}$, i.e. mainly aluminosilicates are depressed.

Based upon the carried out experiment with the use of Aero 9863 collector, the rougher concentrate is received with copper grade of $5.61 \%$ and recovery of $64.94 \%$. With similar consumption of liquid glass at the concentrator combination of amyl xanthogenate and MIBC, rougher concentrate performance is copper grade of $7.18 \%$ with metal recovery of $39.67 \%$.

The introduction of (stage) attritioning operations shows "synergistic effect" that contributes to the maximum cleaner of the mineral surface and, as consequence, to the high quality of the received concentrate. This process let reducing losses with dump tailings by almost half (copper loss decreased from $35.50 \%$ to $17.37 \%$ ). The concentrate of the first recleaner achieved copper grade of $15.1 \%$ with recovery of $47 \%$ at combined mechanical activation with sulfuric acid treatment of the product. At the same time, the combined method of pulp preparation allows to reduce copper losses with dump tailings up to $8.68 \%$.

In closed cycle experiments, the experience of working on high-magnesia talcose ores is taken into account, and approaches tested on ores of this type are implemented in flowsheet solutions. Operations of mechanical activation and regrinding were used as pulp preparation operation. Table 5 shows the results of closed cycle experiments.

Table 5. The results of the locked cycle flotation.

\begin{tabular}{|l|c|c|c|c|c|c|c|}
\hline \multirow{2}{*}{ Products } & \multirow{2}{*}{ Mass pull \%\% } & \multicolumn{3}{|c|}{ Grade, $\%$} & \multicolumn{3}{c|}{ Recovery, \% } \\
\cline { 3 - 8 } & & $C u$ & $A u$ & $A g$ & $C u$ & $A u$ & $A g$ \\
\hline Concentrate & 4.32 & 18.2 & 17.0 & 58.00 & 80.84 & 82.77 & 52.20 \\
\hline Tails & 95.68 & 0.195 & 0.16 & 2.40 & 19.16 & 17.23 & 47.80 \\
\hline Ore & 100.0 & 0.97 & 0.89 & 4.80 & 100.0 & 100.0 & 100.0 \\
\hline
\end{tabular}

The following is noted visually: "dirt" nature of the froth, its increased persistence, and absence of "visible" copper. It is obvious that the froth product is formed by intergrowths with waste rock. As grades of $\mathrm{Fe}$ and $\mathrm{SiO}_{2}$ are approximately equal, and $\mathrm{CaO}$ has decreased by $\sim 10 \%$, the quality of the concentrate mainly suffered due to transition of magnesium-bearing minerals (serpentinite) to the froth product.

The concentrate of the third cleaner consists mainly of copper sulphides (chalcopyrite) by $41.7 \%$ and iron (pyrite, marcasite) by $24.7 \%$. The main part of chalcopyrite is in free form, or in intergrowths with pyrite and iron oxides.

Table 6 presents the chemical composition of scavenger flotation tailings received from the initial sample of serpentine ore, and Figure 4 shows the particle size distribution of this product.

Table 6. Chemical composition of flotation tailings.

\begin{tabular}{|c|c|c|c|}
\hline Element & $\begin{array}{c}\text { Grade, } \\
\%\end{array}$ & Element & Grade, \% \\
\hline $\mathrm{Cu}_{\text {total }}$ & 0.195 & $\mathrm{~K}_{2} \mathrm{O}$ & 0.4 \\
\hline $\mathrm{Cu}_{\text {oxidized }}$ & 0.071 & $\mathrm{Na}_{2} \mathrm{O}$ & 0.038 \\
\hline $\mathrm{Cu}_{\text {secondary }}$ & 0.026 & $\mathrm{TiO}_{2}$ & 0.033 \\
\hline $\mathrm{Cu}_{\text {primary }}$ & 0.083 & $\mathrm{Zn}$ & 0.015 \\
\hline $\mathrm{Fe}_{\text {total }}$ & 6.04 & $\mathrm{~Pb}$ & $<0.005$ \\
\hline $\mathrm{S}_{\text {total }}$ & 4.0 & $\mathrm{As}$ & $<0.001$ \\
\hline $\mathrm{SiO}_{2}$ & 40.0 & $\mathrm{Sb}$ & $<0.002$ \\
\hline $\mathrm{AI}_{2} \mathrm{O}_{3}$ & 2.18 & $\mathrm{Au}, \mathrm{g} / \mathrm{t}$ & 0.16 \\
\hline $\mathrm{CaO}$ & 7.7 & $\mathrm{Ag}, \mathrm{g} / \mathrm{t}$ & 2.40 \\
\hline $\mathrm{MgO}$ & 31.2 & & \\
\hline
\end{tabular}

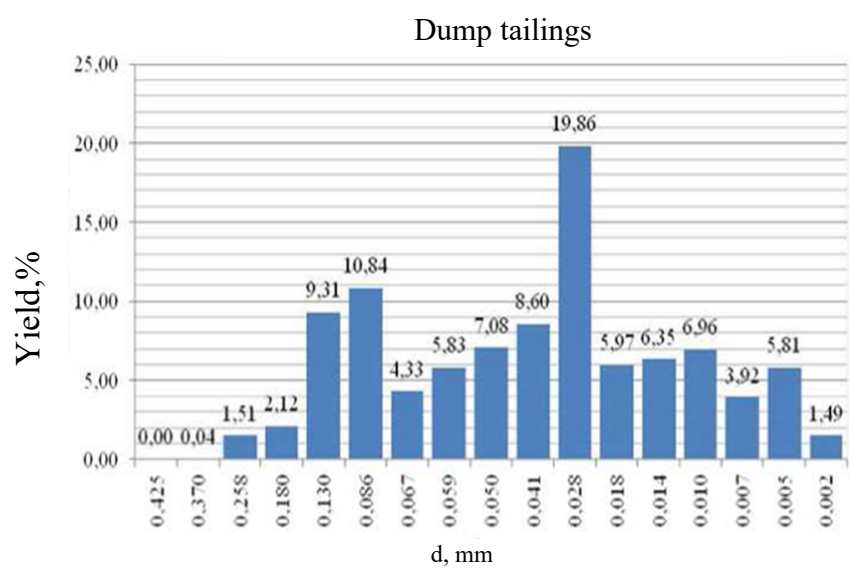

Fig. 4. Particle size distribution of dump tailings in a closed cycle. 


\section{Conclusions}

Main copper losses are associated with chalcopyrite, which is found in intergrowths with non-metallic minerals and polymineral intergrowths together with pyrite and iron oxides. The size of chalcopyrite in such intergrowths is $20-30 \mu \mathrm{m}$, with rare exceptions the chalcopyrite grains with the size of about $70 \mu \mathrm{m}$ are found. Copper losses are associated with presence of complex sulphide hydroxidevalleriite $\mathrm{CuFeS}_{2}\left(\mathrm{Mg}, \mathrm{Fe}, \mathrm{Al}(\mathrm{OH})_{2-3}\right)$ in tailings, which is in close intergrowth with serpentine and thin chalcopyrite (3-5 $\mu \mathrm{m})$. The total grade of copper minerals is $0.3 \%$, pyrite and pyrrhotite $-7.3 \%$, iron oxides -4.0 . Nonmetallic minerals $(88.4 \%)$ are represented by serpentine, pyroxenes, and carbonates.

When assessing the recoverability of individual phases of copper, it can be stated that if recovery of sulphide forms of copper into concentrate was practically preserved at the level of sulphide ores, then recovery of oxidized copper was reduced to $24 \%$. This is mainly due to losses of efficiency of the sulfidizer at the stage grinding, which requires special attention to the formation of the sulphidization regime.

Stage grinding allows increasing total recovery of copper on froth products by $10 \%$. However, the issue of obtaining the high-quality concentrate is not solved - the copper grade remains at the same level, while the copper oxide grade is increased to $40 \%$, which confirms the need to introduce the operation of regrinding of rougher concentrate.

Based upon results of traditional approaches [3-9], it is established that increase in the grinding size, introduction of selective copper collector and additional depressor will allow to assess the prospects for improving the "reagent" direction, and main requirements for the technological flowsheet and reagent suite of processing resistant copper bearing, magnesian serpentinite ores are formed:

- stage grinding to fineness of $95 \%-74 \mu \mathrm{m}$;

- introduction of the depressor for magnesium aluminosilicates;

- introduction of selective collectors for sulphide and oxidized copper;

- finding of the collector for valleriite.

\section{References}

1. S. Mamonov, S. Orlov, S. Volkova. Mining magazine №6. 427-434 (2019)

2. A. Yashchuk, K. Nogaeva, A. Koshanov. Izv. KSTU named after I. Razzak. №28. 293-296 (2013)

3. L. Nazharova Hydrochloric acid processing of serpentinite (author's thesis of the candidate of technical sciences. Kazan, 1999)

4. R. Freidlina, N. Ovchinnikova, A. Gulyakin. Method for complex processing of serpentinite (Patent 2356836 RF, 2009)

5. S. Anufrieva, Yu. Losev, I. Bogdanov International meeting. "Plaksin. chten. -2011" (2011)
6. E. Kim, L. Krylova. International meeting. "Plaksin. chten. -2011" (2011)

7. A. Rakaev, Yu. Neradovsky, E. Chernousenko, T. Morozova. Technological mineralogy, methods of processing mineral raw materials and new materials (Petrozavodsk: Karelian scientific center of the Russian Academy of Sciences, 2010, p. 68-74)

8. S. Karnaukhov, S. Plyasovitsa, N. Ivanova. Ore processing No. 2. p. 19-22 (2018).

9. S. Volkova, S. Mamonov, I. Vlasov. Materials of international scientific practical conference "Modern tendencies in theory and practice of mining and processing of minerals and technogenic raw materials" 313-316 (2019).

10. Beneficiation of asbestos-containing ores https://metallurgist.pro/obogaschenie-asbest/ (2019) 